\title{
Facing the threat: common yellowjacket wasps as indicators of heavy metal pollution
}

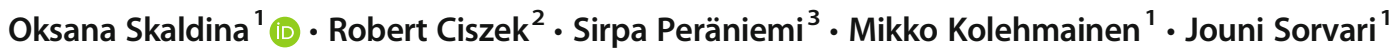

Received: 13 February 2020 / Accepted: 28 April 2020 / Published online: 18 May 2020

(C) The Author(s) 2020

\begin{abstract}
We investigated the common wasp, Vespula vulgaris as a bioindicator and biomonitor of metals in the industrial area. Using traps, we collected 257 yellowjackets along a pollution gradient in the Harjavalta $\mathrm{Cu}-\mathrm{Ni}$ smelter in Southwest Finland. Our method detected metal elements such as arsenic $(\mathrm{As})$, cobalt $(\mathrm{Co})$, copper $(\mathrm{Cu})$, iron $(\mathrm{Fe})$, nickel $(\mathrm{Ni})$, lead $(\mathrm{Pb})$, zinc $(\mathrm{Zn})$, and mercury $(\mathrm{Hg})$ in wasps. The data analyses revealed $\mathrm{V}$. vulgaris can be a proper indicator for $\mathrm{As}, \mathrm{Cd}, \mathrm{Co}, \mathrm{Cu}, \mathrm{Ni}$, and $\mathrm{Pb}$, rather than for $\mathrm{Fe}$ and $\mathrm{Zn}$ contamination. Body burdens of $\mathrm{As}, \mathrm{Cd}, \mathrm{Co}, \mathrm{Cu}, \mathrm{Ni}$, and $\mathrm{Pb}$ decreased with an increase in distance from smelter. Enrichment factor (EF) followed the pattern $\mathrm{Pb}>\mathrm{Cd}>\mathrm{As}>\mathrm{Co}>\mathrm{Cu}>\mathrm{Ni}$. The highest bioaccumulation (BAF) values were revealed for $C d(5.9)$ and the lowest for $P b(0.1)$. Specially designed software (WaspFacer) allowed revealing body burdens of $\mathrm{As}, \mathrm{Cd}, \mathrm{Co}, \mathrm{Cu}, \mathrm{Ni}$, and $\mathrm{Pb}$ to be associated with rather smaller than more asymmetric facial colour markings in yellowjackets. These results add to the body of literature on how heavy metal contaminants can have tangible phenotypic effects on insects and open future opportunities for using wasps as indicators of metal pollution.
\end{abstract}

Keywords Bioindicator $\cdot$ Biomonitor $\cdot$ Biomarker $\cdot$ Colour trait $\cdot$ Heavy metals $\cdot$ Vespula vulgaris

\section{Introduction}

In terrestrial environments, metals originate from a variety of sources such as geogenic, atmospheric, industrial, transport, domestic, agricultural, and pharmaceutical (Martin and Coughtrey 1982). The pathways for metals entering the soil include runoff from industrial sites and roads, metal-based pesticides, phosphate fertilizers, sewer sludge, and atmospheric particle deposition (Gall et al. 2015). Elements such as cobalt

Responsible Editor: Stuart Simpson

Electronic supplementary material The online version of this article (https://doi.org/10.1007/s11356-020-09107-2) contains supplementary material, which is available to authorized users.

Oksana Skaldina

oksana.skaldina@uef.fi

Robert Ciszek

robert.ciszek@uef.fi

Sirpa Peräniemi

sirpa.peraniemi@uef.fi

Mikko Kolehmainen

mikko.kolehmainen@uef.fi
(Co), copper $(\mathrm{Cu})$, iron $(\mathrm{Fe})$, manganese $(\mathrm{Mn})$, molybdenum $(\mathrm{Mo})$, selenium $(\mathrm{Se})$, nickel $(\mathrm{Ni})$, and zinc $(\mathrm{Zn})$ are essential in trace levels as micronutrients for plants, animals, and humans. However, their excessive uptake might cause a toxic effect on organisms (Bodgen and Klevay 2000). The other metals such as arsenic $(A s)$, cadmium $(C d)$, mercury $(H g)$, and lead $(P b)$ have no useful biological function and can have toxic effects even at low concentrations (He et al. 2005). Toxic heavy metals can remain in terrestrial environments for years, accumulating
Jouni Sorvari

jouni.sorvari@uef.fi

1 Department of Environmental and Biological Sciences, University of Eastern Finland, PO Box 1627, FI-70211 Kuopio, Finland

2 A. I. Virtanen Institute for Molecular Sciences, University of Eastern Finland, PO Box 1627, FI-70211 Kuopio, Finland

3 School of Pharmacy, University of Eastern Finland, PO Box 1627, FI-70211 Kuopio, Finland 
in food webs and threatening biota. The impact of accumulating pollution is of paramount concern in localized industrial areas, for example, in areas where metal smelting takes place (Alloway 2012). With this type of pollution, landscape heterogeneity, including agricultural and urban areas, affects the deposition of pollutants and modifies local environmental contamination (Fritsch et al. 2010). Although current levels of industrial heavy metal pollution have been decreasing in the European Union (Tóth et al. 2016; EEA 2018) and the USA (US EPA 2018), the opposite trend is apparent in China ( $\mathrm{Li}$ et al. 2014), African countries (Yabe et al. 2010), and several other developing countries (Krishna and Govil 2005; Mohiuddin et al. 2011). Therefore, efficient, robust, and lowcost methods of monitoring metal pollution are urgently required. Bioindicators may be one such solution, with the concurrent benefits of raising awareness of the utility of biodiversity in environmental monitoring.

In terrestrial environments, several methods are currently used to monitor the rates of metal contamination. First, there are several chemical assessment methodologies, including (i) direct measurements or modelling of metal activities, (ii) metal extraction methods, and (iii) the application of semi-permeable devices for heavy metal analyses in soils (Peijnenburg et al. 2007). The second group of methods is related to microbial biomass and microbial activity (Yuangen et al. 2006). Finally, it is possible to assess environmental contamination by using organisms as bioindicators and biomonitors (Martin and Coughtrey 1982). An indicator can simply indicate the presence or absence of a factor, e.g. heavy metal in this case, while a monitor species can show a biological response to a chemical dosage (Markert et al. 1999). Considering biomonitors, a biomarker approach has been intensively adopted in risk assessment frameworks over the last 20 years, making it a valuable complement to ecotoxicity testing (Amiard-Triquet et al. 2013). A biomarker can be defined as a biochemical, cellular, physiological, morphological, or behavioural change which can be observed in body tissues or fluids or at the level of the whole organism that reveals the exposure or the effects of one or more chemical pollutants (Depledge 1994). The major benefit of biomarkers is that they are sensitive early warning tools to assess environmental health.

Within terrestrial ecosystems, several plants and parts of the plants are used for biological monitoring purposes. The most frequent are mosses (Berg and Steinnes 1997), lichens (Bargagli 2016), trees (Sawidis et al. 2011), and bark from trees and shrubs (El-Hasan et al. 2002), as well as leaves and conifer needles from trees and shrubs (Aksoy and Öztürk 1997; Pietrzykowski et al. 2014). Although birds (Costa et al. 2012) and small mammals (Talmage and Walton 1991) are used as bioindicators and biomonitors, terrestrial invertebrates have several benefits. They are abundant organisms, with growth rates and a population turnover midway between microorganisms and higher plants and animals (Hodkinson and Jackson 2005). Invertebrates are usually in close contact with contaminants in
Fig. 1 Study species (A and B) and sampling method, study area (C and D), and a beer trap (E). The study area names in this study: 1: Torttila, 2: Gate, 3: Nummi, 4: Hiite, 5: Nakkila. Photographs A and B were purchased with the standard licence from Shutterstock, (C) Daniel Prudec. All rights reserved

the soil. Measurements of heavy metals from soil samples revealed that metal concentrations could be highly spatially heterogeneous (Salminen and Haimi 1999). Therefore, invertebrate bioindicators might better reveal the environmental quality than soil samples. There are significant differences in the metal bioaccumulation of various invertebrate taxa: high in the Isopoda and low in the Coleoptera (Heikens et al. 2001). For some taxa, the data is limited or not presented. Although a diverse range of insects has been studied regarding its usefulness in bioindication and biomonitoring (Heikens et al. 2001; Nummelin et al. 2007), only limited information exists for the social wasps (Hymenoptera, Vespidae) (but see Kowalczyk and Watala 1989; Urbini et al. 2006; Polidori et al. 2018). Recently, it has been stressed that metal contamination can increase disease susceptibility in social insects (Feldhaar and Otti 2020). Therefore, such studies possess wider ecological implications than just bioindication.

Here, we addressed two questions. First, we aimed to determine whether Vespula yellowjacket wasps accumulate local industry-originated heavy metals in their bodies and thus whether they are suitable environmental bioindicators for industrial heavy metal contamination. We attempted to achieve this aim by collecting samples across a pollution gradient near a $\mathrm{Cu}-\mathrm{Ni}$ smelting area in Finland, and by conducting further analyses of individual metal levels in wasp bodies using inductively coupled plasma mass spectrometry (ICP-MS).

In a range of species, the colouration has been shown as a metal-sensitive trait, reflecting the accumulation of metals in organisms and indicating environmental metal contamination (Pérez et al. 2010; Lifshitz and St Clair 2016; Skaldina and Sorvari 2017; Skaldina et al. 2018). Therefore, in the second aim, we intended to identify any colour traits in faces of yellowjacket wasps that could be associated with industrial metal contamination, suggesting the ways these traits can assist current biomonitoring programmes. To do this, we assessed facial melanin markings with specially designed software-the WaspFacer.

\section{Materials and methods}

\section{Study species}

The common yellowjacket wasp Vespula vulgaris (Hymenoptera, Vespidae) (Fig. 1A) is a eusocial species with an annual life cycle. It is both native and invasive to the Holarctic region (Dvorák 2007), and invasive in Australia, Tasmania, New Zealand, 


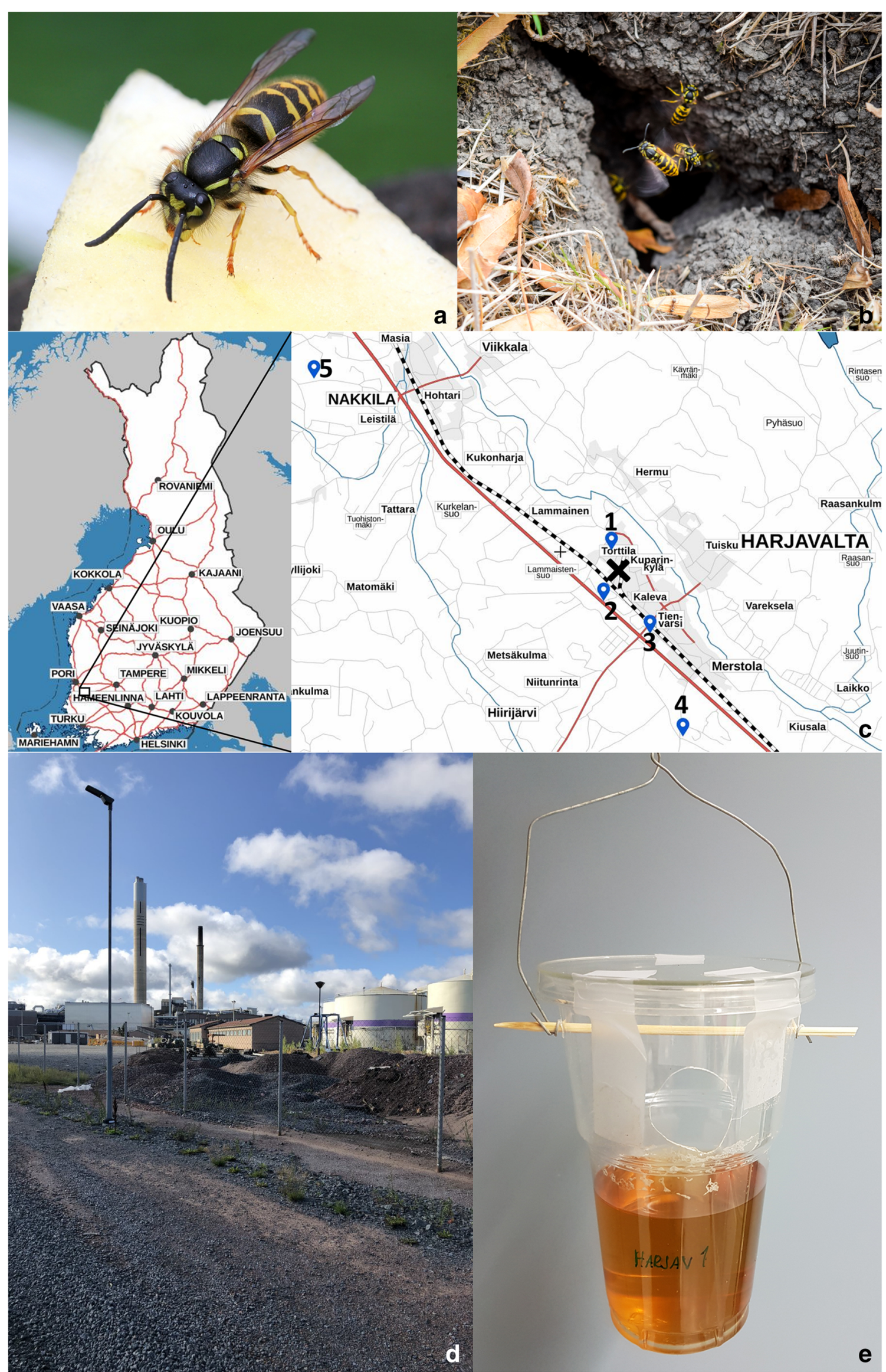


Hawaii, and South America (Mathews et al. 2000; CABI 2019; Lester and Beggs 2019). Yellowjackets are highly flexible in their nesting and foraging habits and consequently occur in both natural and anthropogenic landscapes. $V$. vulgaris build carton nests in mammal-made holes in the ground, hollow trees, or in anthropogenic cavities (e.g. attics, disused chimneys, sheds) (Fig. 1B). Therefore, the wasp colonies are usually in close proximity to the soil. V. vulgaris is a generalist predator of both grounddwelling and flying arthropods (Richter 2000). To feed brood, it preys on Diptera (flies), Lepidoptera (moths), Araneae (spiders) (Harris and Oliver 1993), and ants (Formicidae) (Harris 1991). The adult wasps widely consume carbohydrates such as fruit, flower nectar, and aphid honeydew to maintain their energy resources, and they collect wood pulp for the nest construction (Greene 1991). Nesting and feeding preferences of this species, therefore, predispose both adults and their offspring to the uptake of heavy metals from different strata of the terrestrial environment and considering these wasps as bioindicators and biomonitors of metal pollution.

\section{Study area}

We sampled wasps at the Harjavalta town and its vicinities $\left(61^{\circ} 19^{\prime} \mathrm{N}, 22^{\circ} 9^{\prime} \mathrm{E}\right)$ in South-Western Finland in August 2014. In that area, the dominant tree was Scots pine, Pinus sylvestris $\mathrm{L}$., and the dominant forest scrub species varied from Vaccinium to Calluna; the soil type was ferric podzol (Derome and Lindroos 1998). Harjavalta is the largest heavy metal polluted zone in Finland, but the area of forest death there is still less than $1 \mathrm{~km}^{2}$ (Salemaa et al. 2001). The local source of pollution is a copper-nickel smelter, emitting heavy metals and sulphur during the last 50 years. Besides main metals such as $\mathrm{Cu}$ and $\mathrm{Ni}$, emissions from the smelter contain arsenic $\mathrm{As}, \mathrm{Cd}, \mathrm{Pb}, \mathrm{Fe}, \mathrm{Hg}$, and $\mathrm{Zn}$ (HELCOM 2002). In addition, $\mathrm{Co}$ is a common by-product of the $\mathrm{Ni}$-mining process; for example, a typical nickel slug contains $0.1 \%$ of $C o$ (Riekkola-Vanhanen 1999). Thus, some cobalt pollution might be also depicted in the studied area.

At Harjavalta, the emission of heavy metals started to decrease from the beginning of 1990s; a steep decrease was noticed in $\mathrm{Ni}$ concentrations, but less marked in $\mathrm{Cu}$. That decrease was primarily due to novel technical modifications to the smelter (e.g. installations of new filters) and the construction of a taller smokestack (Berglund et al. 2015). Current levels of pollution in Harjavalta do not pose toxicological risks for humans and wildlife (Eeva et al. 2018). Anyway, due to existing and long-term industrial pollution, in the vicinity of a smelter soil still contain elevated metal concentrations (Berglund et al. 2015). A clear decreasing gradient for soil concentrations of metals such as $\mathrm{Cd}, \mathrm{Cu}, \mathrm{Fe}, \mathrm{Ni}, \mathrm{Pb}$, and $Z n$ was revealed at the distances $0.5,2,4$ and $8 \mathrm{~km}$ from the smelting plant (Derome and Lindroos 1998). The overall ecosystems' conditions follow a similar gradient of distance. In the immediate proximity to plant $(<1 \mathrm{~km})$, heavy metal pollution has variable detectable effects on organisms' survival, reproduction, and biodiversity (Kiikkilä 2003). At about $2 \mathrm{~km}$ from the smelter, clear signs of nutrient cycling disturbance are still visible. At 4-km distance, there are noticeable changes in species composition, although the effects of pollution are not so acute anymore. At $8 \mathrm{~km}$, the overall ecosystem can be classified as undisturbed with only slight changes in the understory vegetation. For this reason, we carried out a sampling campaign at five study sights across the pollution gradient at a distance ranged from 0.86 to $10.66 \mathrm{~km}$ (Fig. 1C) from the smelting plant (Fig. 1D).

\section{Sample collection and pre-processing}

A total of 257 wasps were collected at the area across the pollution gradient $(\leq 10.66 \mathrm{~km}$ to smelter) using a beertrapping method (Fig. 1D) (Sorvari 2013). Altogether 20 beer traps were left out for 1-week period in early August 2014. GPS coordinates were taken to identify the location of each trap. A detailed description of the locations' distance to the smelter, number of traps, and wasps per location is given in the supplementary table (Table S1A). The distance between the nearest-neighbour traps ranged from 20 to $50 \mathrm{~m}$, and the maximum distance between traps within the same location was $200 \mathrm{~m}$. After remaining for 1 week in the field, the traps were emptied, and wasps from each trap were placed in plastic tubes in a freezer at a temperature of $-20{ }^{\circ} \mathrm{C}$. As shown by Braun et al. (2009), short periods $(<2$ weeks $)$ of insects' presence in trapping fluids did not result in metal leaching or cross-contamination of samples. Also, no effects of a short stay in beer have been previously observed to affect wasps' colouration. Later, we identified $V$. vulgaris specimens using the identification key by Dvořák and Roberts (2006).

\section{Digital photographing and image pre-processing}

The wasp faces were photographed using a Nikon DS-Fi1 microscope camera (5-megapixel CCD) and DS Camera Control Unit attached to an Olympus SZX9 trinocular microscope with a magnification of $\times 16$. The photographs were taken with NIS-Elements BR imaging software version 3.2 in a windowless room under stable light conditions (058 PAR) and saved as 8-bit RGB images. One person carried out photographic imaging over 2 days in September 2017. To obtain good-quality photographs in a stable position, and to avoid additional metal contamination, we fixed each wasp in small plastic tubes. We also carried out all manipulations with nitrile examination gloves and used only plastic or wooden materials to perform the manipulations. Digital photographs of the wasps' thoraxes were additionally taken for the size measurements. 


\section{Photographic analyses: WaspFacer}

To ease the analysis of the different parameters of the facial colour markings of the wasps, we developed a new opensource software tool-WaspFacer (Fig. 2). The software was implemented using MATLAB 2018b and can be downloaded from https://rciszek.github.io/WaspFacer. The purpose of the software was to enable a fast and semiautomatic method for the analysis of colour traits, which facilitated the processing of larger sample sets to assist research and biomonitoring. WaspFacer enabled the fast and convenient assessment of several parameters for each anchor-shaped facial colour marking (Fig. 2A). These parameters were (i) a continuous symmetry distance (CSD) here and after a continuous symmetry measure (CSM), (ii) the Procrustes distance (PD), (iii) the area difference (AD), and (iv) the area of melanisation (MA). A detailed description of the program and the scored parameters and reasoning for selecting facial colour parameters is available at the supplement S2.

\section{Size and weight measurements}

The size measurements included the head width (HW) and thorax width (TW) in millimetres $(\mathrm{mm})$ and were taken from the digital photographs using the WaspFacer and ImageJ software. The HW was measured as the maximum interocular distance, which was the distance between the concavities of the wasps' compound eyes (Karsai and Hunt 2002) and the TW was measured as an intertegular distance, which is the distance between the bases of the right and left wings - the tegulas. This distance had been confirmed as a reliable estimator for the individual body size in Aculeata (Greenleaf et al. 2007; Karsai and Hunt 2002). Measurements of individual dry body mass are further described in the next subsection. Dry body mass also better predicts body size due to reduced variation from water content (Ohl and Thiele 2007).

\section{Heavy metal analysis}

The following metal elements were quantified from individual yellowjacket samples: arsenic $(A s)$, cadmium $(C d)$, cobalt $(C o)$, copper $(\mathrm{Cu})$, iron $(\mathrm{Fe})$, mercury $(\mathrm{Hg})$, nickel $(\mathrm{Ni})$, lead $(\mathrm{Pb})$, and zink $(Z n)$ using inductively coupled plasma mass-spectrometer (ICP-MS). The calibration of the instrument was done using a certified solution standard (TraceCERT Periodic Table Mix 1 and Mercury standards for ICP, Sigma-Aldrich). Element isotopes without known spectral interferences were preferentially selected for analysis. A triple-quadrupole reaction system was used to remove polyatomic interferences for elements that do not have abundant, interference-free isotopes. The reaction

a

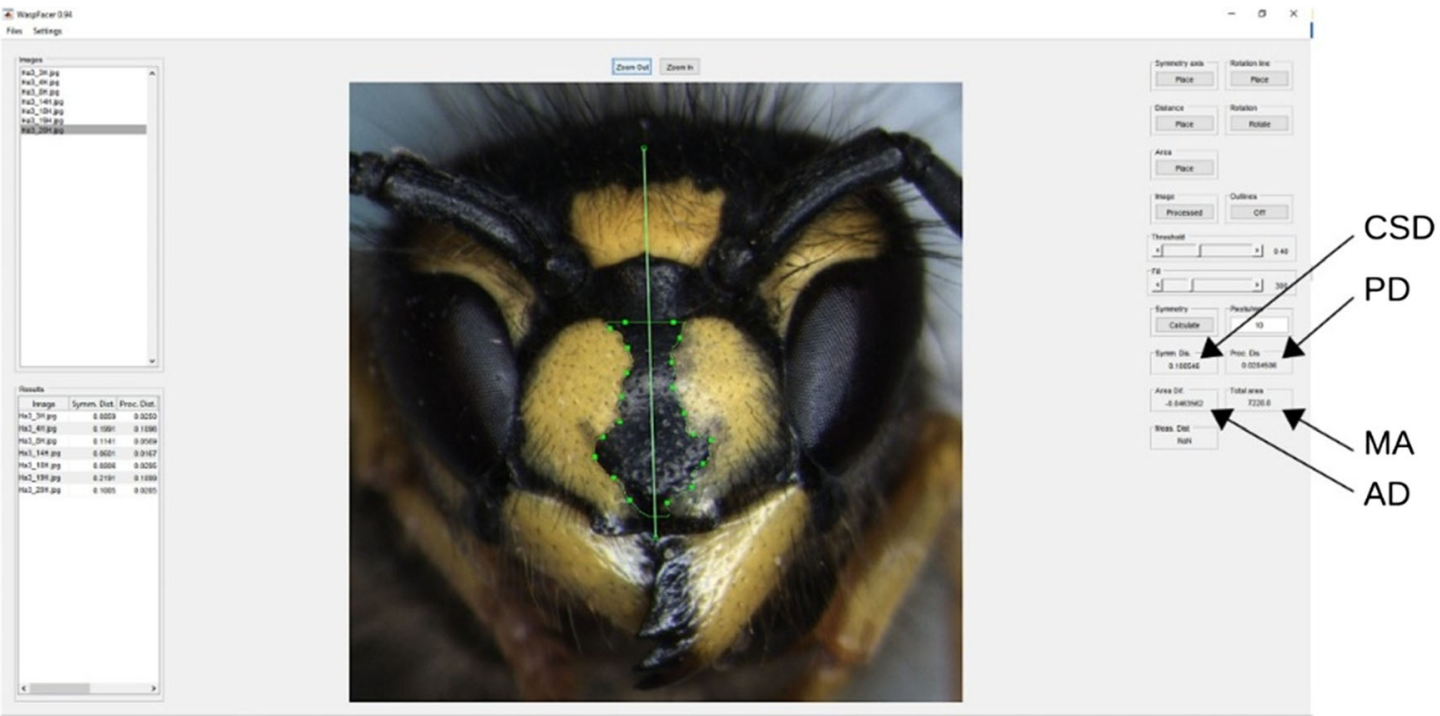

b
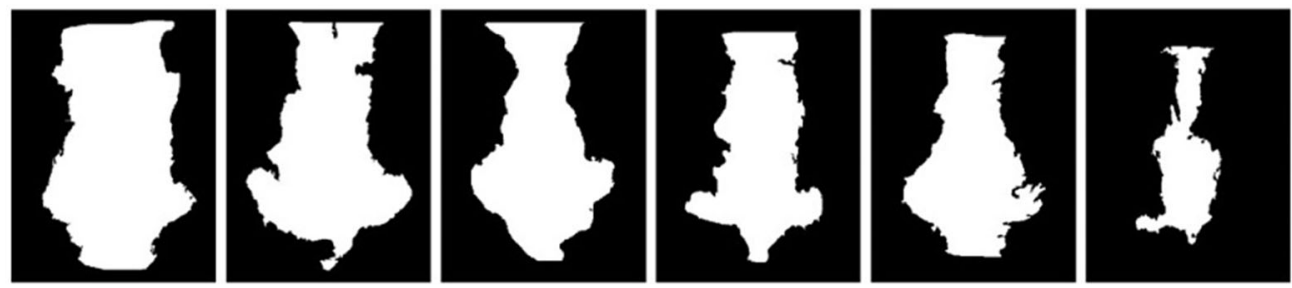

Fig. 2 A view of the WaspFacer and facial colour trait analyses of Vespula vulgaris. (A) The user interface with a single analysed image. The vertical green line denotes the symmetry axis defined by the user. Scored parameters are continuous symmetry distance (CSD) same as a

continuous symmetry measure $(\mathrm{CSM})$; Procrustes distance $(\mathrm{PD})$; area difference (AD); melanisation area (MA). (B) A set of exported bitmap images of the segmented facial markings 
system was operated in collision mode with kinetic energy discrimination (KED), using helium as the cell gas $\left(3.7 \mathrm{~mL} \mathrm{~min}^{-1}\right)$. A peristaltic pump and nebuliser were used for sample injection. Three internal standards, litium-6, rhodium-103, and uranium238 , were mixed online with the samples to compensate for matrix effects and instrument drift. Method blanks and certified standard reference material NIST® SRM® 1577b Bovine Liver (Sigma-Aldrich) were measured in addition to the unknown samples for each batch of analysis to check for contamination and to confirm the accuracy of the analysis batch. After the photographs were taken, all the wasps were dried in an oven Termarks 8000 for $48 \mathrm{~h}$ at $60{ }^{\circ} \mathrm{C}$ and cooled down for $48 \mathrm{~h}$ in a desiccator at $20{ }^{\circ} \mathrm{C}$ to prevent additional moisture. Then we measured the individual dry body mass $\left(\mathrm{M}_{\mathrm{b}}\right.$ or d.w.) to the nearest $0.001 \mathrm{mg}$ using a Metler Toledo MX5 analytical balance. This was needed because an analysis for heavy metal levels was performed for each wasp individually. Wasp samples $(0.015-0.020 \mathrm{~g})$ were dissolved with a microwave digestion system using the MARS $^{\text {TM }} 6$ iWave instrument (CEM Corporation, USA) and the Animal Tissue method in $8 \mathrm{ml}$ of $\mathrm{HNO}_{3}$ (TraceMetal ${ }^{\mathrm{TM}}$ grade, Fisher Scientific) using MARSXpress teflon digestion vessels. Simultaneous performance of analytical blanks and certified reference material confirmed the method accuracy was within acceptable limits. After digestion, the samples were diluted to $20 \mathrm{~mL}$ with de-ionized water (USF Elga Maxima). The determination of metal concentrations was performed with NexION 350D ICP-MS (PerkinElmer, USA) equipped with ESI prepFAST autosampler (Elemental Scientific, USA). The detection limit for most of the elements was approximately $0.0001 \mu \mathrm{g} / \mathrm{g}$. The range of detected metals in wasps' tissues is presented in microgrammes per gramme on a dry weight.

\section{Statistics and index calculation}

Enrichment factor $(\mathrm{EF})$ was calculated as suggested by Nieminen et al. (2002) and Eeva et al. (2018). Mean element concentrations in the highly polluted area $(\leq 2 \mathrm{~km})$ were divided by mean element concentrations in the less polluted area $(\geq 4 \mathrm{~km})$ in a sample type (wasps: $\mu \mathrm{g} / \mathrm{g}$, d.w.). Bioaccumulation factor (BAF) was calculated as the average metal concentration in wasps $(\mu \mathrm{g} / \mathrm{g}$, d.w.) divided by average topsoil concentrations ( $\mu \mathrm{g} / \mathrm{g}$, d.w.) in the highly exposed zone $(<2 \mathrm{~km})$. We used soil concentration for the elements such as $\mathrm{As}, \mathrm{Cd}, \mathrm{Co}, \mathrm{Cu}, \mathrm{Ni}$, and $\mathrm{Pb}$ reported for the distance $0.9 \mathrm{~km}$ from the smelter by Ruiz et al. (2017). BAF indexes for $\mathrm{Fe}, \mathrm{Co}$, and $\mathrm{Zn}$ were not calculated as no appropriate soil references were found. Soil $Z n$ concentrations provided by Kiikkilä (2003) were 17 years old, therefore cannot be considered for the research purposes in the current paper.

Distribution of heavy metals was normalised by logarithmic transformation except for EF and BAF indexes. We used a Pearson coefficient to reveal the correlation between levels of heavy metals and the distance from the smelting plant, for revealing correlation between metal values, and for revealing correlations between several metal elements and between phenotypic characteristics. A principal component analysis (procedure FACTOR in SAS) was done for eight intercorrelated heavy metal elements using Varimax rotation and Kaiser normalization. Analyses of the effects of logarithmical distance on the PCs were done using linear mixed models (LMM, the MIXED procedure in SAS); models' residuals were normally distributed.

Analyses of the body size differences, and several colour traits and metal levels were performed using linear mixed models (LMM, the MIXED procedure in SAS). Since the average foraging distance of $V$. vulgaris is $80 \mathrm{~m}$ (Richter 2000), and the traps were placed in the field at a distance of 20-50 m, trap identity was not used as a random factor in the models. However, the sampling location was used as a random factor in analyses on the association between metal levels and distance to the smelter complex. All pairwise comparisons were made using the Tukey-Kramer test. All mean values are presented with 95\% confidence intervals. Phenotypic characteristics were analysed in model that requires normality of model residuals, which was fulfilled. The analyses were carried out using the SAS statistical software, version 9.4 (SAS Institute Inc.).

\section{Results}

\section{Heavy metal load}

The ICP-MS method revealed the presence of metal elements and their body burdens in yellowjackets $(\mu \mathrm{g} / \mathrm{g}, \mathrm{d}$.w.) such as As-from 0.7 to 40.7 ; cobalt $\mathrm{Co}$-from 0.1 to $841, \mathrm{Cu}$-from 28 to 289 ; $C d$-from 0.1 to $19.9 ; \mathrm{Fe}$-from 143 to 8316 ; $\mathrm{Ni}$-from 0.7 to $5502 ; \mathrm{Pb}$-from 0.1 to $18.3 ; \mathrm{Zn}$-from 50 to 13,381 . Because $\mathrm{Hg}$ was found in wasps only from two of the closest locations to the smelter (Torttila and Gate), we did not perform further analyses for that element. Mean values for body burdens of these elements, EF and BAF values, are presented in Table 1. The highest values for the EF were

Table 1 Mean values (mean $\pm \mathrm{SD}$ ) for the individual yellowjackets' body burdens $(\mu \mathrm{g} / \mathrm{g}$, d.w.) of the main heavy metal pollutants in high $(\leq$ $2 \mathrm{~km}$ ) and lower $(>4 \mathrm{~km})$ exposure zones, enrichment factor $(\mathrm{EF})$, and bioaccumulation factor (BAF), shown for soil $\rightarrow$ wasps transfer routes for the polluted areas ( $n=257$ wasps)

\begin{tabular}{lllll}
\hline Element & Higher exposure area & Lower exposure area & EF & BAF \\
\hline $\mathrm{As}$ & $7.94 \pm 5.36$ & $1.69 \pm 1.08$ & 4.7 & 1 \\
$\mathrm{Cd}$ & $2.35 \pm 2.91$ & $0.44 \pm 0.43$ & 5.4 & 5.9 \\
$\mathrm{Co}$ & $2.27 \pm 6.65$ & $0.92 \pm 2.93$ & 2.5 & - \\
$\mathrm{Cu}$ & $98.7 \pm 51.3$ & $47.4 \pm 12.5$ & 2.1 & 0.4 \\
$\mathrm{Fe}$ & $398 \pm 909$ & $244 \pm 358$ & 1.7 & - \\
$\mathrm{Ni}$ & $75.6 \pm 429$ & $38.3 \pm 196$ & 2 & 1.5 \\
$\mathrm{~Pb}$ & $2.25 \pm 2.36$ & $0.31 \pm 0.22$ & 7.3 & 0.1 \\
$\mathrm{Zn}$ & $787 \pm 1385$ & $707 \pm 618$ & 1.1 & - \\
\hline
\end{tabular}


revealed for $P b$ (7.3), $C d$ (5.4), As (4.7), $C o$ (2.5), $C u$ (2.1), and $\mathrm{Ni}$ (2); lower values were found for $\mathrm{Fe}$ (1.7) and $\mathrm{Zn}$ (1.1). The highest BAF values were revealed for $C d(5.9)$ and the lowest for $P b(0.1)$.

The levels of $\mathrm{As}, \mathrm{Cd}, \mathrm{Co}, \mathrm{Cu}, \mathrm{Ni}$, and $\mathrm{Pb}$ negatively correlated with the logarithmic distance from the smelting plant. For $Z n$, the correlation was weakly positive, yet significant; weak negative, but marginally non-significant correlation was revealed for $\mathrm{Fe}$ (Table S1 B). All elements had significant intercorrelated values, except $Z n$, which correlated only with $\mathrm{Co}$ and weakly with $\mathrm{Fe}$ (Table S1 C).

A principal component analysis (PC) for metal concentrations from individual wasp samples revealed two PCs with eigenvalues over one (PC1: 4.53 and PC2: 1.22). PC1 explained $56.59 \%$ of the variance and was associated with $A s$, $C d, C u$, and $P b$; PC2 explained $15.19 \%$ and was associated mainly with $\mathrm{Ni}$ and $\mathrm{Co}$ (Table 2). PC1 ( $\mathrm{As}, \mathrm{Cd}, \mathrm{Cu}$, and $\mathrm{Pb}$ ) decreased with an increasing logarithmic distance from the smelting plant $\left(F_{1,255}=31.00, p<0.0001\right.$; Fig. 3A). Similar negative association was found for PC2 $\left(F_{1,255}=11.6, p=\right.$ 0.0008 ; Fig. 3B). In addition, both $\mathrm{PC} 1$ and $\mathrm{PC} 2$ values differed significantly between the studied areas (PC1: $F_{4,252}=$ 25.7; $p<0.0001$ : Fig. 3A; PC2: $F_{4,252}=3.92, p=0.0042$ Fig. $3 \mathrm{~B})$.

\section{Colour traits and heavy metals}

To check if facial colour traits in yellowjackets can reflect heavy metal pollution, we analysed the traits such as MA, $\mathrm{AD}, \mathrm{PD}$, and CSM of the anchor-shaped melanin marking and the interrelationship of those traits with the logarithmic distance to smelter and heavy metal body burden. Closer to smelter $(<2 \mathrm{~km})$ and further away $(>4 \mathrm{~km}) \mathrm{V}$. vulgaris differed in the MA $\left(F_{4,252}=23.2, p<0.0001\right.$; Fig. 4A; Table 3$)$ and $\mathrm{AD}\left(F_{4,252}=7.2, p<0.0001\right.$; Fig. 4B). However, no significant differences were revealed for $\operatorname{CSM}\left(F_{4,252}=1.11, p=\right.$ $0.353)$ and $\mathrm{PD}\left(F_{4,252}=0.79, p=0.531\right)$. These findings

Table 2 Correlations between logarithmically transformed metal eigenvalues and two principal components (PC1 andPC2)

\begin{tabular}{|c|c|c|}
\hline & \multicolumn{2}{|c|}{ Rotated factor pattern } \\
\hline & PC1 & PC2 \\
\hline $\mathrm{Fe}$ & 0.081 & 0.225 \\
\hline Co & 0.338 & 0.498 \\
\hline$N i$ & 0.165 & 0.893 \\
\hline $\mathrm{Cu}$ & 0.401 & 0.231 \\
\hline$Z n$ & -0.013 & -0.017 \\
\hline As & 0.483 & 0.276 \\
\hline$C d$ & 0.869 & 0.176 \\
\hline $\mathrm{Pb}$ & 0.303 & 0.224 \\
\hline
\end{tabular}
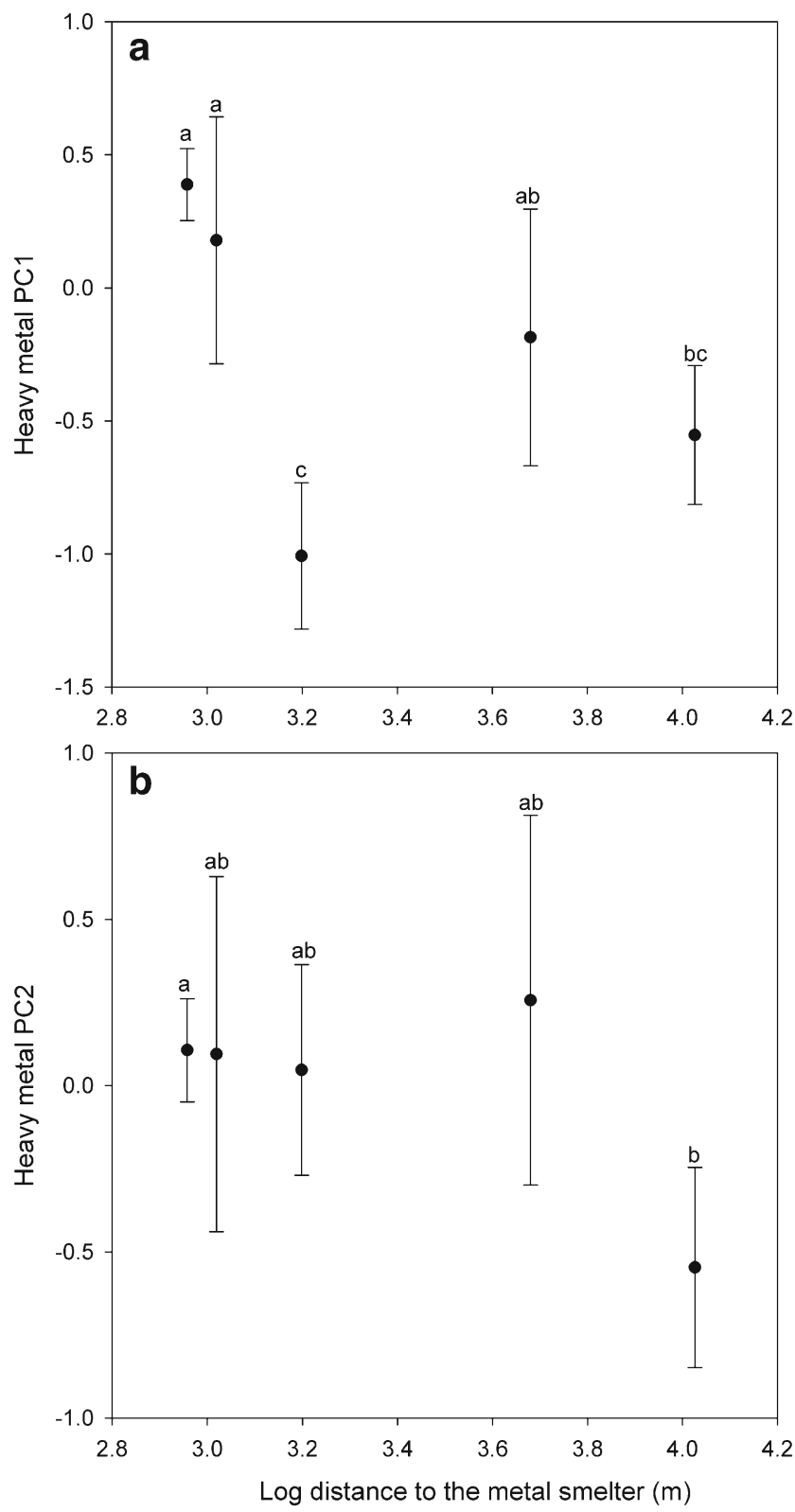

Fig. 3 The association between (A) PC1 ( $A s, C d, C u$, and $P b)$ and (B) PC2 (Ni and Co) and the logarithmic distance of the wasps' traps $(n=20)$ to the Harjavalta $\mathrm{Cu}$ - $\mathrm{Ni}$ smelting plant. Symbols for the sites from left to right: Torttila, Gate, Nummi, Hiite, and Nakkila. The different letters above the symbols indicate significant pairwise differences between the areas (Tukey's test $p<0.05$ )

suggested that closer to smelter wasps had significantly smaller area of facial colour markings and smaller difference between right and left part of the marking. MA and $\mathrm{AD}$ decreased with increasing levels of $C u, A s, C d$, and $P b$, and increase of $\mathrm{Ni}$ and $\mathrm{Co}$ decreased all parameters (MA, AD, PD, CSM) except $C o$ for AD (Table S1 D).

Further, we checked if melanin facial colour traits of yellowjackets were associated with body size parameters, measured as $(i)$ head width (HW), (ii) thorax width (TW), 

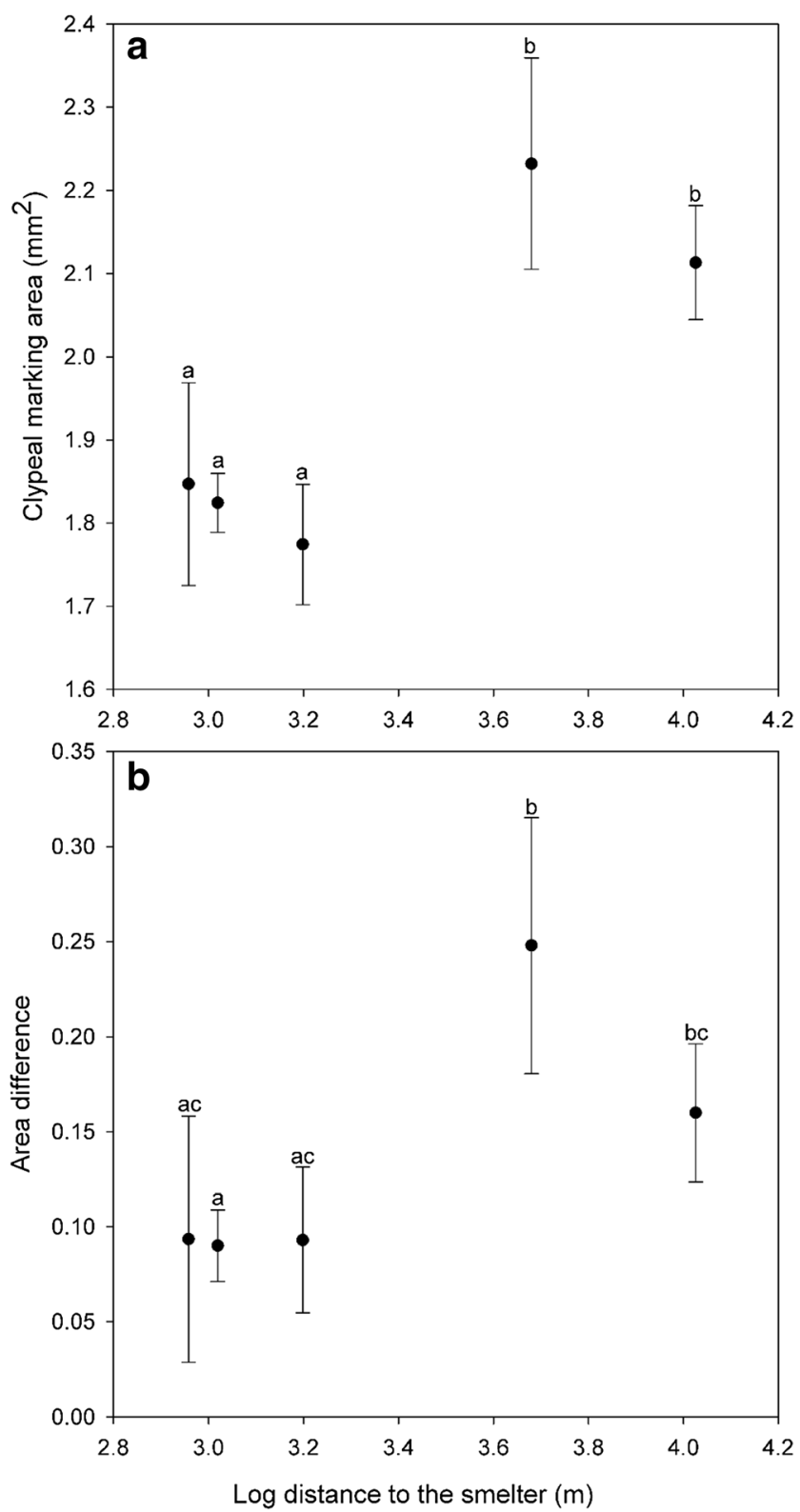

Fig. 4 (A) The difference in the area of clypeal melanisation (MA in $\mathrm{mm}^{2}$ ) and (B) distinctions in (non-directional left/right differences) in the area of clypeal melanisation (AD in $\mathrm{mm}^{2}$ ) of $V$. vulgaris, collected along the pollution gradient (logarithmical distance to the smelting plant). The symbols of the sites from left to right: Torttila, Gate, Nummi, Hiite, and Nakkila. Different letters above the symbols indicate significant pairwise differences between areas (Tukey's test $p<0.05$ )

and (iii) dry body mass $\left(\mathrm{M}_{\mathrm{b}}\right)$. All body size parameters were weakly correlated between each other $\left(\mathrm{M}_{\mathrm{b}} \times \mathrm{HW}: r=0.26\right.$, $p<0.0001 ; \mathrm{M}_{\mathrm{b}} \times \mathrm{TW}: r=0.24, p<0.0001 ; \mathrm{HW} \times \mathrm{TW}: r=$ $0.27, p<0.0001)$. A between-area comparison using linear mixed model analyses revealed that the yellowjackets significantly differed in HW: $F_{4,252}=8.72, p=0.0001$; TW: $F_{4,252}=4.9, p=0.0008$ and $\mathrm{M}_{\mathrm{b}}\left(F_{4,252}=2.87, p=0.024\right)$ along the pollution gradient at the five study sites (Table 3 ).
Table 3 Estimated marginal means (mean \pm SD) for the head width (HW), thorax width (TW), body mass $\left(\mathrm{M}_{\mathrm{b}}\right)$, and melanisation area of the clypeus (MA) in yellowjackets $(n=257)$ from high exposure areas (Torttila, Gate, Nummi) and lower exposure (Hiite and Nakkila) areas

\begin{tabular}{llrrr}
\hline & HW $(\mathrm{mm})$ & TW $(\mathrm{mm})$ & \multicolumn{1}{l}{$\mathrm{M}_{\mathrm{b}}(\mathrm{mg})$} & $\mathrm{MA}\left(\mathrm{mm}^{2}\right)$ \\
\hline Torttila & $2.64 \pm 0.01$ & $2.5 \pm 0.02$ & $16.21 \pm 0.31$ & $1.85 \pm 0.12$ \\
Gate & $2.62 \pm 0.05$ & $2.5 \pm 0.07$ & $16.66 \pm 1.05$ & $1.82 \pm 0.04$ \\
Nummi & $2.61 \pm 0.03$ & $2.4 \pm 0.04$ & $17 \pm 0.62$ & $1.77 \pm 0.07$ \\
Hiite & $2.53 \pm 0.05$ & $2.4 \pm 0.07$ & $17.6 \pm 1.09$ & $2.23 \pm 0.13$ \\
Nakkila & $2.57 \pm 0.03$ & $2.4 \pm 0.04$ & $16.87 \pm 0.05$ & $2.11 \pm 0.07$ \\
\hline
\end{tabular}

\section{Discussion}

\section{Common wasps as bioindicators of industrial $\mathrm{Cu}-\mathrm{Ni}$ pollution}

Our results confirmed that yellowjackets indicate $\mathrm{As}, \mathrm{Cd}, \mathrm{Co}$, $\mathrm{Cu}, \mathrm{Ni}$, and $\mathrm{Pb}$ industrial contamination. Right next to the smelting plant and at the distance up to $2 \mathrm{~km}$ away, they accumulated metal elements in amounts at least two times higher, compared to reference areas. Although $\mathrm{Fe}$ and $\mathrm{Zn}$ were also detected in wasps, there was almost no difference in those between zones. Predatory insects differ in their capability for metal accumulation. Thus, waterstriders (Hemiptera, Gerridae) and antlions (Neuroptera, Myrmeleontidae) were shown as good bioindicators for $\mathrm{Fe}$ and dragonfly (Odonata) larvae as bioindicators for $Z n$ (Nummelin et al. 2007). However, our data did not reveal $V$. vulgaris as a bioindicator for $\mathrm{Fe}$ and $\mathrm{Zn}$, although in the environments with predominated $\mathrm{Fe}$ or $\mathrm{Zn}$ exposure, the situation might be different.

The revealed order of the metal content decrease in wasps was consistent with that reported by Migula et al. (2013) for the spiders (Araneae) but differed from the grasshoppers (Orthoptera) (Karadjova and Markova 2014). Both spiders and wasps are top-level predators, in which bioaccumulation might be dependent on their "hunting behaviour, chemical load in prey, gender, age, season and an intensity of exposure to metals" (Migula et al. 2013). Compared to other elements, essential metals such as $\mathrm{Zn}, \mathrm{Fe}$, and $\mathrm{Cu}$ reached the highest concentrations in wasps. Insects normally need these metals for energy production, nutrient metabolism, and gene regulation; however, their excess can disrupt gene expression, cause enzyme malfunction, and lead to oxidative stress (Merritt and Bewick 2017). For the model insect organism Chironomus ramosus (Diptera, Chironomidae), median lethal concentrations $\left(\mathrm{LC}_{50}\right)$ for copper $\left(\mathrm{CuSO}_{4} \times 24 \mathrm{~h}\right)$ exposure were determined as $3280 \mu \mathrm{g} / \mathrm{g}$ (acute toxicity) and $1.8 \mu \mathrm{g} / \mathrm{g}$ after 21-day exposure (chronic toxicity) (Majumdar and Gupta 2012). However, for the yellowjackets, acute and chronic toxicity doses for $\mathrm{Cu}$ and other essential metals (e.g. $\mathrm{Fe}, \mathrm{Mn}, \mathrm{Zn}$ ) have not been yet revealed. 
Several previous studies provide a clear proof that in Harjavalta, there is a decreasing gradient of soil-deposited metals (Derome and Lindroos 1998; Kiikkilä 2003; Ruiz et al. 2017). We revealed that when assessing distance as a gradient, body burdens for the elements such as $\mathrm{As}, \mathrm{Cu}, \mathrm{Co}, \mathrm{Cd}, \mathrm{Fe}, \mathrm{Ni}$, and $\mathrm{Pd}$ in wasps were decreasing, but not the concentrations of $Z n$. Del Toro et al. (2010) previously got similar results for the granivorous ant Pogonomyrmex rugosus (Hymenoptera, Myrmicinae), revealing a decrease of these elements $(\mathrm{As}, \mathrm{Cu}, \mathrm{Cd}, \mathrm{Pd})$ with distance from the $\mathrm{Cu}-\mathrm{Pb}$ smelter in Chihuahuan Desert (Mexico, USA). Similarly, Eeva et al. (2004) identified decreasing gradient for $\mathrm{As}, \mathrm{Cu}, \mathrm{Pd}$, and for $\mathrm{Ni}$ concentrations in red wood ants (Formica s. str) in Harjavalta. Contrary, any decline in the concentrations of $\mathrm{Cu}$ and $\mathrm{Pb}$ in several predatory insects such as waterstriders, antlions, and dragonflies was found by Nummelin et al. (2007) in the vicinity of the Koverhar ironsteel factory. Given examples might confirm that some insect species, as a common wasp in our case, might not simply indicate the presence or absence of a contaminant in the environment but also reflect the gradient for its decrease.

When comparing internal body concentrations with soil concentrations in different invertebrates, it has been shown that the slope for metal accumulation patterns (BAFs) decreased in the order: $\mathrm{Pb}>\mathrm{Cd}>\mathrm{Cu}$ (Heikens et al. 2001). However, similarly to our results (the highest BAF values were revealed for $C d$; lower for $P b$ and $C u$ in wasps), the same tendency existed for the ants (BAFs: seeds $\rightarrow$ ants) (Del Toro et al. 2010). For $C d$, both $\mathrm{EF}$ and BAF values were high in our samples, which can be the evidence for the dependence of $C d$ accumulation in wasps on soil metal concentration in the environment. Although $\mathrm{EF}$ for $\mathrm{Pb}$ in $\mathrm{V}$. vulgaris was even higher, its BAF value was the lowest. This finding might indicate the predominant role of the other than soil exposure source (might be contaminated food) of $\mathrm{Pb}$ accumulation in common wasps. Previous studies on heavy metals in wasps confirmed the high capability of these insects for $C d$ (Kowalczyk and Watala 1989) and $P b$ accumulation (Urbini et al. 2006; Polidori et al. 2018). Here, we for the first time revealed the capability of wasps for $A s$ and $C u$ accumulation. As accumulation might depend on the subgroup of invertebrates (Moriarty et al. 2009) and has been previously shown to be high in ants (Eeva et al. 2004; Moriarty et al. 2009).

In addition, aquatic insects are important vectors for the transfer of arsenic from lakes and streams to terrestrial predators (Mogren et al. 2013). Previously, Tarvainen et al. (1997) showed that, in the industrialized southwest region of Finland, there were elevated concentrations of As in surface waters, and its elevated levels correlated with high levels of $\mathrm{Cu}$. In Harjavalta, there is a river Kokemäenjoki, located at less than $2 \mathrm{~km}$ to the smelter. The aquatic insects, inhabiting that river, might be an important source of metal exposure to wasps. Wasps might take up metals mostly with their food (Hopkin 1989). They have diverse diet, including carbohydrates such as honeydew from insects' excretions or flower nectar (Spradbery 1973), protein-based food-arthropods from the orders Hemiptera, Lepidoptera (Harris 1991), Diptera, Hymenoptera, and Araneae (Harris and Oliver, 1993) or lipid-rich seed appendages - elaiosomes (Jules 1996). Therefore, in terrestrial environments, there are many sources for wasps' exposure to heavy metals, which might be considered in future research.

\section{V. vulgaris as a biomonitor for heavy metal pollution}

We revealed that near to Harjavalta $\mathrm{Cu}-\mathrm{Ni}$ smelter, common wasps possessed decreased areas of their facial melanin-based colour traits. That was associated with elements such as $A s, C d$, $\mathrm{Co}, \mathrm{Cu}, \mathrm{Ni}$, and $\mathrm{Pb}$. Pollution did not apparently result in the increased asymmetry of that facial colour markings; however, some association between $\mathrm{Ni}$ and $\mathrm{Co}$ with facial pattern asymmetry was found. The finding that $V$. vulgaris workers had smaller areas of melanisation on their faces closer to the metal smelting plant was consistent with our previous results. Ants (Formica lugubris) had less melanised heads in industrially polluted environments (Skaldina et al. 2018). Describing the interrelation between metals and melanin pigments, McGraw (2003) suggested that melanin could bind metals, which might result in increased melanized areas. However, this may be dependent on the species-specific metal deposition areas, which in insects are commonly midgut, fat body, Malpighian tubules, and sometimes exocuticle (Ballan-Dufrançais 2002; Lukáň 2009). Insects use the following mechanisms to tolerate heavy metal pollution: $(i)$ avoidance of the exposure source, (ii) limited uptake of contaminants, (iii) immobilization and (iv) elimination of metals, and (v) metal excretion (Heikens 2001; Grześ 2010; Migula et al. 2013). Immobilization of metals occurs via encapsulation, which in insects requires melanin pigments (Nakhleh et al. 2017). Then in polluted environments, there might be a cost to produce melaninbased colour traits. Metal encapsulation in $V$. vulgaris was already shown by Polidori et al. (2018). Therefore, decreased areas of facial melanin colour patterns in common wasps from polluted environments might be explained by a trade-off for melanin utilization needed for metals detoxification and encapsulation over colour pattern development.

The impact of metals on terrestrial ecosystems and the distinct species depends on the metal bioavailability and bioaccessibility and also on the species' reaction (Luoma and Rainbow 2005). Previously, it has been shown that heavy metals can have diverse ecotoxicological effects on insects. Intensive $P b$ exposure resulted in smaller morphological traits in aphids (Görür, 2006) and in decreased body mass in beetles (Osman et al. 2015). $C d$ caused metabolic disorders in ants (Migula et al. 1993); in combination with $\mathrm{Hg}$, it provoked increased mortality rates (Migula et al. 1997). Consistently with the other studies (Osman et al. 2015; Zhan et al. 2017), including our own (Skaldina et al. 2018), insects may suffer a reduced body mass in response to heavy metal pollution. 
Combined metals might affect insects' development in various ways. For example, elevated $Z n$ increased the growth rate, while excess $C d$ has been seen to reduce the survival of aphids (Stolpe and Müller 2016). Cu, Fe, and $\mathrm{Zn}$ might act as micronutrients (Bodgen and Klevay 2000), resulting in body size increase. However, as previously revealed for ground beetles (Osman et al. 2015) and wild bees (Moroń et al. 2014), $C d$ might be specifically responsible for a body mass decrease. Recently, body size was shown as a predictor of mortality for several aquatic insects (Cadmus et al. 2020). More studies are needed to reveal if there are similar trends for the terrestrial insects, especially for predatory wasps.

\section{Conclusions}

The common wasp $V$. vulgaris can be used as a bioindicator for revealing metals such as $A s, C d, C o, C u, N i$, and $\mathrm{Pb}$, rather than for $\mathrm{Fe}$ and $\mathrm{Zn}$. However, this might change in the environments with the other metal exposure sources. Our results confirmed that concentrations of metals ( $\mathrm{As}, \mathrm{Cd}, \mathrm{Co}, \mathrm{Cu}, \mathrm{Ni}$, and $P b$ ) gradually decreased with the distance from the smelter and had the highest enrichment values in wasps from higher exposure areas. Same metal elements were associated with decreased areas of facial melanin-based patterns in yellowjackets. These associations allowed to consider $V$. vulgaris as a biomonitor species for heavy metal pollution. We suggest the size rather than asymmetry of facial melaninbased colour patches as a morphological biomarker of metal exposure. The decrease in the area of melanin-based markings might be explained with a trade-off between physiological investment of melanin into encapsulation (detoxifying mechanism) of metal ions versus investment into colouration. Body size parameters in wasps were affected by metal loads; however, the results were not straightforward. As stated by Hodkinson and Jackson (2005), "the ideal system is inexpensive, simple, easy to implement, quick, reliable, and easily understood by non-professionals". Our method of the assessment of phenotypic characteristics in V. vulgaris, the WaspFacer, provides a simple and convenient tool to conduct large-scale biomonitoring research using social wasps as biomonitor agents and for developing novel biomarkers for various pollutants.

Acknowledgements Open access funding provided by University of Eastern Finland (UEF) including Kuopio University Hospital. We thank Sonja Holopainen for her assistance with our ICP-MS analyses. We are kindly thankful to Seirian Sumner and anonymous reviewers for their critical comments and suggestions to the manuscript, which helped to significantly improve its quality.

Funding information The study was financially supported by Jenny and Antti Wihuri Foundation fellowship to OS (grants no 00180353 and 00190336).
Open Access This article is licensed under a Creative Commons Attribution 4.0 International License, which permits use, sharing, adaptation, distribution and reproduction in any medium or format, as long as you give appropriate credit to the original author(s) and the source, provide a link to the Creative Commons licence, and indicate if changes were made. The images or other third party material in this article are included in the article's Creative Commons licence, unless indicated otherwise in a credit line to the material. If material is not included in the article's Creative Commons licence and your intended use is not permitted by statutory regulation or exceeds the permitted use, you will need to obtain permission directly from the copyright holder. To view a copy of this licence, visit http://creativecommons.org/licenses/by/4.0/.

\section{References}

Aksoy A, Öztürk MA (1997) Nerium oleander L. as a biomonitor of lead and other heavy metal pollution in Mediterranean environments. Sci Total Environ 205:145-150

Alloway BJ (2012) Sources of heavy metals and metalloids in soils. In: Alloway BJ (ed) Heavy metals in soils: trace metals and metalloids in soils and their bioavailability. Springer, Dordrecht, pp 11-50

Amiard-Triquet C, Amiard-Triquet J-C, Rainbow PS (2013) Conclusions: biomarkers in environmental risk assessment. In: Amiard-Triquet C, Amiard J-C, Rainbow PS (eds) Ecological biomarkers: indicators of ecotoxicological effects. CRC Press, Boca Raton, pp 411-434

Ballan-Dufrançais C (2002) Localization of metals in cells of pterygote insects. Microsc Res Technol 56:403-420

Bargagli R (2016) Moss and lichen biomonitoring of atmospheric mercury: a review. Sci Total Environ 572(1):216-231

Berg T, Steinnes E (1997) Use of mosses (Hylocomium splendens and Pleurozium schreberi) as biomonitors of heavy metal deposition: from relative to absolute deposition values. Environ Pollut 98(1): $61-71$

Berglund ÅMM, Rainio MJ, Eeva T (2015) Temporal trends in metal pollution: using bird excrement as indicator. PLoS One 10(2): e0117071

Bodgen JD, Klevay LM (2000) Clinical nutrition of the essential trace elements and minerals. Humana press, New Jersey

Braun M, Simon E, Fábián I, Tóthmérész B (2009) The effects of ethylene glycol and ethanol on the body mass and elemental composition of insects collected with pitfall traps. Chemosphere 77:1447-1452

Cadmus P, Kotalik CJ, Jefferson AL, Wheeler SH, McMahon AE, Clements WH (2020) Size-dependent sensitivity of aquatic insects to metals. Environ Sci Technol 54(2):955-964

Costa RA, Eeva T, Eira C, Vaqueiro J, Vingada JV (2012) Assessing heavy metal pollution using Great Tits (Parus major): feathers and excrements from nestlings and adults. Environ Monit Assess 185(6): $5339-5344$

Del Toro I, Floyd K, Gardea-Torresdey J, Borrok D (2010) Heavy metal distribution in Chihuahan Desert Rough Harvester ant (Pogonomyrmex rugosus) populations. Environ Pollut 158:12811287

Depledge MH (1994) The rational basis for the use of biomarkers as ecotoxicological tools. In: Fossi MC, Leonzio C (eds) Nondestructive biomarkers in vertebrates. Lewis Publishers, Boca Raton, pp 271-295

Derome J, Lindroos A (1998) Effects of heavy metal contamination on macronutrient availability and acidification parameters in forest soil in the vicinity of the Harjavalta $\mathrm{Cu}-\mathrm{Ni}$ smelter, SW Finland. Environ Pollut 99:225-232 
Dvořák L (2007) Social wasps (Hymenoptera: Vespidae) trapped with beer in European forest ecosystems. Act Mus Morav Sc Biol 92: 181-204

Dvořák L, Roberts SPM (2006) Key to the paper and social wasps of the Central Europe (Hymenoptera: Vespidae). Acta Entomol Mus Nat Pragae 46:221-244

Eeva T, Sorvari J, Koivunen V (2004) Effects of heavy metal pollution on red wood ant (Formica s. str) populations. Environ Pollut 158: 1281-1287

Eeva T, Holmström H, Espín S, Sanchez-Virosta P, Klemola T (2018) Leaves, berries and herbivorous larvae of bilberry Vaccinium myrtillus as sources of metals in food chains at a $\mathrm{Cu}-\mathrm{Ni}$ smelter site. Chemosphere 210:859-866

El-Hasan T, Al-Omari H, Jiries A, Al-Nasir F (2002) Cypress tree (Cupressus semervirens L.) bark as an indicator for heavy metal pollution in the atmosphere of Amman city, Jordan. Environ Int 28(6):513-519

European Environment Agency (EEA) (2018) https://www.eea.europa. eu/highlights/environmental-pressures-from-industrys-heavy . Accessed 15 December 2018

Feldhaar H, Otti O (2020) Pollutants and their interaction with diseases of social Hymenoptera. Insects 11(3):153

Fritsch C, Giraudoux P, Cœurdassier M, Douay F, Raoul F, Pruvot C, Waterlot C, de Vaufleury A, Scheifler R (2010) Spatial distribution of metals in smelter-impacted soils of woody habitats: influence of landscape and soil properties, and risk for wildlife. Chemosphere 81(2):141-155

Gall JE, Boyd RS, Rajakaruna N (2015) Transfer of heavy metals through terrestrial food webs: a review. Environ Monit Assess 187:201

Görür G (2006) Effects of heavy metal accumulation in host plants to cabbage aphid (Brevicoryne brassicae) - morphology. Ekologia (Bratislava) 25(3):314-321

Greene A (1991) Dolichovespula and Vespula. In: Ross KG, Matthews RW (eds) The social biology of wasps. Cornell University Press, New York, pp 263-305

Greenleaf SS, Williams NM, Winfree R, Kremen C (2007) Bee foraging ranges and their relationship to body size. Oecologia 153:589-596

Grześ I (2010) Ants and heavy metal pollution - a review. Eur J Soil Biol 46:350-355

Harris RJ (1991) Diet of the wasps Vespula vulgaris and V. germanica in honeydew beech forest of the South Island, New Zealand. New Zeal J Zool 18:159-169

Harris RJ, Oliver EH (1993) Prey diets and population densities of the wasps Vespula vulgaris and $V$. germanica in scrubland pasture. New Zeal J Ecol 17(1):5-12

He ZL, Yang XE, Stoffella PJ (2005) Trace elements in agroecosystems and impacts on the environment. J Trace Elem Med Biol 19(2-3): $125-140$

Heikens A, Peijnenburg WJGM, Hendriks AJ (2001) Bioaccumulation of heavy metals in terrestrial invertebrates. Environ Pollut 113:385393

HELCOM (2002) PITF 19/2002, document 5.2/19: emissions of Outokumpu Harjavalta metals OY and development of environmental affairs in the 1990's. Accessed 19 September 2019

Hodkinson ID, Jackson JK (2005) Terrestrial and aquatic invertebrates as bioindicators for environmental monitoring, with particular reference to mountain ecosystems. Environ Manag 35(5):649-666

Hopkin SP (1989) Ecophysiology of metals in terrestrial invertebrates. Elsevier Applied Science Publisher, UK

Invasive Species Compendium (CABI) (2019) datasheet/56675 https:// www.cabi.org/isc. Accessed 15 March 2019

Jules ES (1996) Yellow jackets (Vespula vulgaris) as a second seed disperser for the myrmecohorous plant Trillium ovatum. Am Mid Natur 135(2):367-369
Karadjova I, Markova E (2014) Metal accumulation in insects (Orthoptera, Acrididae) near a copper smelter and copper-flotation factory (Pirdop, Bulgaria) Biotechnol Biotechnol Equip 23:204-207

Karsai I, Hunt JH (2002) Food quantity affect traits of offspring in the paper wasp Polistes metricus (Hymenoptera, Vespidae). Environ Entomol 31(1):99-106

Kiikkilä O (2003) Heavy-metal pollution and remediation of forest soil around the Harjavalta $\mathrm{Cu}-\mathrm{Ni}$ smelter, in SW Finland. Silva Fenn 37(3):399-415

Kowalczyk JK, Watala C (1989) Content of some heavy metal ions in various developmental stages of the social wasp Dolichovespula saxonica (Fabr.) (Hymenoptera, Vespidae). Bull Environ Contam Toxicol 43:415-420

Krishna AK, Govil PK (2005) Heavy metal distribution and contamination in soils of thane-Belapur industrial development area, Mumbai, Western India. Environ Geol 47(8):1054-1061

Lester PJ, Beggs JR (2019) Invasion success and management strategies for social Vespula wasps. Annu Rev Entomol 64:51-71

Li Z, Ma Z, van der Kuijp TJ, Yuan Z, Huang L (2014) A review of soil heavy metal pollution from mines in China: pollution and health risk assessment. Sci Total Environ 468-469:843-853

Lifshitz N, St Clair CC (2016) Coloured ornamental traits could be effective and non-invasive indicators of pollution for wildlife. Conserv Physiol 4:1-16

Lukán̆ M (2009) Heavy metals in alpine terrestrial invertebrates. Oecologia Mont 18:31-38

Luoma SN, Rainbow PS (2005) Why is metal bioaccumulation so variable? Biodynamics as a unifying concept. Critical Rev Environ Sci Technol 39(7):1921-1931

Majumdar TN, Gupta A (2012) Acute and chronic toxicity of copper on aquatic insects Chironomus ramosus from Assam, India. J Environ Biol 33:139-142

Markert B, Wappelhorst O, Weckert V, Herpin U, Siewers U, Friese K, Breulmann G (1999) The use of bioindicators for monitoring the heavy-metal status of the environment. J Radioana Nucl Chem 240(2):425-429

Martin MH, Coughtrey PJ (1982) Biological monitoring of heavy metal pollution: land and air. Applied Science Publishers, London

Mathews RW, Goodisman M, Austin AD, Bashford R (2000) The introduced English wasp Vespula vulgaris (L.) (Hymenoptera: Vespidae) newly recorded invading native forests of Tasmania. Austral $\mathrm{J}$ Entomol 39:177-179

McGraw K (2003) Melanins, metals and mate quality. Oikos 102(2):402406

Merritt TJC, Bewick AJ (2017) Genetic diversity in insect metal tolerance. Front Genet 8:172

Migula P, Wilczek G, Babczynska A (2013) Effects of heavy metal contamination. In: Wolfgang N (ed) Spider Ecophisiology. Springer, Verlag, pp 403-414

Migula P, Nuorteva P, Nuorteva S-L, Glowacka E, Oja A (1993) Physiological disturbances in ants (Formica aquilonia) to excess of cadmium and mercury in a Finnish forest. Sci Total Environ 134:1305-1314

Migula P, Glowacka E, Nuorteva S-L, Nuorteva P, Tulisalo E (1997) Time-related effects of intoxication with cadmium and mercury in the red wood ant. Ecotoxicology 6:307-320

Mogren CL, Walton WE, Parker DR, Trumble JT (2013) Trophic transfer of arsenic from an aquatic insect to terrestrial insect predator. PLoS One 8(6):e67817

Mohiuddin KM, Ogawa Y, Zakir HM, Otomo K, Shikazono N (2011) Heavy metals contamination in water and sediments of an urban river in a developing country. Int J Environ Sci Technol 8(4):723736

Moriarty MM, Koch I, Gordon RA, Reimer KJ (2009) Arsenic speciation of terrestrial invertebrates. Environ Sci Technol 43(13):4818-4823 
Moroń D, Szentgyörgyi H, Skórka P, Potts SG, Woyciechowski M (2014) Survival, reproduction and population growth of the important pollinator bee Osmia rufa along gradients of heavy metal pollution. Insect Conserv Divers 7(2):113-121

Nakhleh J, Moussawi LE, Osta MA (2017) The melanization response in insect immunity. Advan Ins Physiol 52:83-109

Nieminen TM, Ukonmaahano L, Shotyk W (2002) Enrichment of Cu, Ni, $\mathrm{Zn}, \mathrm{Pb}$ and $\mathrm{As}$ in an ombrotrophic peat bog near a $\mathrm{Cu}-\mathrm{Ni}$ smelter in Southwest Finland. Sci Total Environ 292:81-89

Nummelin M, Lodenius M, Tulisalo E, Hirvonen H, Alanko T (2007) Predatory insects as bioindicators of heavy metal pollution. Environ Pollut 145(1):339-347

Ohl M, Thiele K (2007) Estimating body size in apoid wasps: the significance of linear variables in a morphologically diverse taxon (Hymenoptera, Apoidea). Zoosystem Evol 83(2):110-124

Osman W, El-Samad LM, Mokhamer E-H, El-Touhamy A, Shonouda M (2015) Ecological, morphological and histological studies on Blaps polycresta (Coleoptera: Tenebrionidae) as biomonitors of cadmium soil pollution. Environ Sci Pollut Res 22(18):14104-14115

Peijnenburg WJGM, Zablotskaya M, Vijver M (2007) Monitoring metals in terrestrial environments within a bioavailability framework and a focus on soil extraction. Ecotoxicol Environ Saf 67(2):163-179

Pietrzykowski M, Socha J, van Doorn NS (2014) Linking heavy metal bioavailability $(\mathrm{Cd}, \mathrm{Cu}, \mathrm{Zn}$ and $\mathrm{Pb})$ in Scots pine needles to soil properties in reclaimed mine areas. Sci Total Environ 470-471: 501-510

Polidori C, Pastor A, Jorge A, Pertusa J (2018) Ultrastructural alterations of midgut epithelium, but not greater wing fluctuating asymmetry, in paper wasps (Polistes dominula) from urban environments. Microsc Microanal 24(2):183-192

Richter MR (2000) Social wasps (Hymenoptera: Vespidae) foraging behaviour. Annu Rev Entomol 45:121-150

Riekkola-Vanhanen M (1999) Finnish expert report on best available techniques in nickel production. Finnish Environment Institute, Helsinki, 64 pp

Ruiz SR, Espín S, Sánchez-Virosta P, Salminen J-P, Lilley T, Eeva T (2017) Vitamin profiles in two free-living passerine birds under a metal pollution gradient - a calcium supplementation experiment. Ecotoxicol Environ Saf 138:242-252

Salemaa M, Vanha-Majamaa I, Derome J (2001) Understory vegetation along a heavy metal pollution gradient in SW Finland. Environ Pollut 112:339-350

Salminen J, Haimi J (1999) Horizontal distribution of copper, nickel and enchytraeid worms in polluted soils. Environ Pollut 104:351-358
Sawidis T, Breuste J, Mitrovic M, Pavlovic P, Tsigaridas K (2011) Trees as bioindicator of heavy metal pollution in three European cities. Environ Pollut 159(12):3560-3570

Skaldina O, Sorvari J (2017) Biomarkers of ecotoxicological effects in social insects. In: Kesari K (ed) Perspectives in environmental toxicology. Springer International Publishing, Switzerland, pp 203-214

Skaldina O, Peräniemi S, Sorvari J (2018) Ants and their nests as indicators for industrial heavy metal contamination. Environ Pollut 240: $574-581$

Sorvari J (2013) Social wasp (Hymenoptera: Vespidae) beer trapping in Finland 2008-2012: a German surprise. Entomol Fenn 24(3):156164

Spradbery JP (1973) Wasps. An account of the biology and natural history of social and solitary wasps. Lindon, Sidgwick and Jackson

Stolpe C, Müller C (2016) Effects of single and combined heavy metals and their chelators on aphid performance and preferences. Environ Toxicol Chem 35(12):3023-3030

Talmage SS, Walton BT (1991) Small mammals as monitors for environmental contaminants. Rev Environ Contam Toxicol 119:47-145

Tarvainen T, Lahermo P, Mannio J (1997) Sources of trace metals and headwater lakes in Finland. Water Air Soil Pollut 94(1-2):1-32

Tóth G, Hermann T, Da Silva MR, Montanarella L (2016) Heavy metals in agricultural soils of the European Union with implications for food safety. Environ Internat 88:299-309

United States Environmental Protection Agency (US EPA) (2018) https://www.epa.gov/air-trends/particulate-matter-pm10-trends , Accessed 15 December 2018

Urbini A, Sparvoli E, Turilazzi S (2006) Social wasps as bioindicators: a preliminary research with Polistes dominulus (Hymenoptera, Vespidae) as a trace metal accumulator. Chemosphere 64(5):697703

Yabe J, Ishizuka M, Umemura T (2010) Current levels of heavy metal pollution in Africa. J Vet Med Sci 72(10):1257-1263

Yuangen Y, Campbell CD, Clark L, Cameron CM, Paterson E (2006) Microbial indicators of heavy metal contamination in urban and rural soils. Chemosphere 63(11):1942-1952

Zhan H, Zhang J, Chen Z, Huang Y, Ruuhola T, Yang S (2017) Effects of $\mathrm{Cd}^{2+}$ exposure on key life history traits and activities of four metabolic enzymes in Helicoverpa armigera (Lepidopteran: Noctuidae). Chem Ecol 33(4):325-338

Publisher's note Springer Nature remains neutral with regard to jurisdictional claims in published maps and institutional affiliations. 